\title{
Ibn Taymiyya on the Incoherence of the Theologians' Universal Law: Reframing the Debate between Reason and Revelation in Medieval Islam
}

\author{
CARL SHARIF EL-TOBgUI (Brandeis University, Waltham, MA)
}

\begin{abstract}
This article analyzes the overarching themes and goals of Ibn Taymiyya's roughly forty arguments against the philosophers' and theologians' "Universal Law" for the figurative interpretation of scripture, to which he dedicates approximately 500 pages of his 10-volume Dar' ta'ärud al-'aql wa'l-naql. While Ibn Taymiyya himself presents these arguments in a disjointed and seemingly random fashion, this study demonstrates that by carefully breaking down, regrouping, and reconstructing them, we can discern a coherent attempt on Ibn Taymiyya's part to reconfigure the very terms of the debate between reason and revelation in medieval Islam in several important ways. Firstly, he deconstructs what it means for reason to "ground" our knowledge of revelation. Next, he redefines the opposition at stake not as one of "reason vs. revelation," but as a purely epistemological question of certainty vs. conjecture, with both reason and revelation serving as potential sources of both kinds of knowledge. Finally, he builds on this insight to replace the dichotomy "shar ' $\bar{l}-{ }^{\prime} a q l \bar{l}$," in the sense of "revelational vs. rational," with the dichotomy "shar $\bar{l}-$ bid ' $"$ " in the sense of "scripturally validated vs. scripturally non-validated," arguing that revelation itself both commends and exemplifies the valid use of reason and rational argumentation. By this move, Ibn Taymiyya attempts to introduce a new paradigm in which it is the epistemic quality of a piece of knowledge alone that counts, simultaneously subsuming reason itself into the larger category of "shar î," or revelationally validated, sources of knowledge.
\end{abstract}

Key words: Ibn Taymiyya, reason and revelation, Universal Law (al-qānūn al-kullì), ta'wīl, figurative interpretation, Dar' ta'ärud al-'aql wa'l-naql

\section{Introduction}

In his massive, 10-volume Dar' ta'ärud al-'aql wa'l-naql, or "The Refutation of the Contradiction of Reason and Revelation," Taqī al-Dīn Ibn Taymiyya (d. 728/1328) attempts to settle once and for all a central debate that had raged among Muslim theologians and philosophers for more than six centuries. This debate centers on the nature, role, and limits of human reason and its proper relationship to, and interpretation of, Divine Revelation. In the Dar' $t a^{c} \bar{a} r u d$, Ibn Taymiyya — who has been characterized as "one of the most original and systematic thinkers in the history of Islam" "-attempts to transcend the reason vs.

1 Yossef RAPOPORT and Shahab AHMED, "Ibn Taymiyya and His Times," in Ibn Taymiyya and His 
revelation dichotomy altogether by breaking down and systematically reconstituting the very categories in terms of which reason was conceived and debated in medieval Islam.

In concrete terms, the debate over reason and revelation among classical Muslim scholars centered primarily on the question of when and under what circumstances it was admissible to practice $t a^{\prime} w \bar{l} l$, or figurative interpretation, on the basis of a "rational objection" (mu'ârid 'aqlī) to the plain sense of a Qur'ānic verse or passage. Of particular concern in this respect were those passages containing descriptions of God whose literal meaning seemed to entail tashbih, an unacceptable assimilation of God to created beings. Some such attributes as were (apparently) affirmed in revelation were held by various groups - particularly the philosophers, the Mu'tazila, and later Ash'arites - to be rationally indefensible on the grounds that their straightforward affirmation would amount to tashbi h. In such cases, a conflict was thought to ensue between the clear dictates of reason and the equally clear statements of revelation, resulting in the unsettling notion that there exists a fundamental contradiction between revelation and reason-both of which have nevertheless been accepted as sources of true knowledge.

The question of how to deal with such "rational objections" to the plain sense of revelation elicited various kinds of responses from both philosophers and theologians, ultimately culminating in the "Universal Law" (al-qānūn al-kullì), which Ibn Taymiyya paraphrases on the very first page of the Dar' ta ${ }^{\text {ca }}$ rud as it had come to be formulated by the time of the famous Ash'arite theologian Fakhr al-Dīn al-Rāzī (d. 606/1209) in the $6^{\text {th }} / 12^{\text {th }}$ century. This Law, in brief, requires that in the event of a conflict between reason and revelation, the dictates of reason be given priority and revelation be reinterpreted accordingly via $t a^{3} w \bar{l} l$, or figurative interpretation. This prescription is justified on the consideration that it is reason that "grounds" our assent to the truth of revelation, such that any gainsaying of reason in the face of a revealed text would undermine both reason and revelation together.

In pursuit of his mission to resolve the conflict between reason and revelation, Ibn Taymiyya devotes roughly 500 pages of the Dar' ta $^{\mathbf{C}} \overline{\mathrm{r}} \mathrm{rud}$ (most of volumes I and v) to the elaboration of around thirty-eight separate $\operatorname{arguments}^{2}$ (wajh, pl. wujūh-lit., "aspects" or "viewpoints") against the logical coherence of the theologians' Universal Law and the integrity, in purely theoretical terms, of the premises and assumptions upon which it is based. These thirty-eight arguments concern the validity of the Universal Law alone and do not touch upon any substantive philosophical or theological debates per se. In the remainder of the work, Ibn Taymiyya takes up what seems to be practically all of the actual instances

Times, ed. Yossef Rapoport and Shahab Ahmed (Oxford: Oxford University Press, 2010), 19.

2 The text itself lists forty-four arguments, six of which, however, are not "arguments" directed against the Universal Law itself. Rather, they address substantive philosophical and theological questions, usually at such length that they end up trailing off into an extended disquisition on one topic after another, eventually dissipating into the larger body of the text. Argument 19, for instance, begins on $\mathrm{p}$ 320 of Vol. I and does not address the Universal Law at all. Rather, it takes up the philosophical argument for the existence of God based on the temporal origination of movements and accidents (dali hudūth al-harakāt wa'l-a'rāọ), a discussion which then meanders from one topic to another over the course of the next three volumes. It is not until one comes to the first page of Vol. $\mathrm{V}$ that one finally reads, "al-Wajh al-'Ishrün" ('Argument 20'), which is itself an extended substantive back and forth that spans 200 pages, or half the volume.

jais • 18 (2018): 63-85 
of alleged conflict between reason and revelation raised by various philosophical and theological schools over the seven-century career of the Islamic intellectual tradition that preceded him.

The purpose of the present article is to provide a presentation and analysis of Ibn Taymiyya's main arguments in the Dar' ta'ārud against the theologians' Universal Law, attempting along the way to highlight the major epistemological renovations he seeks to accomplish in doing so. Through these arguments, he attacks both the Law's logical coherence, as well as the main epistemic categories and assumptions upon which it is based. While Ibn Taymiyya himself presents his thirty-eight arguments in a disjointed and seemingly random fashion, I demonstrate that by carefully breaking down, regrouping, and reconstructing them, we can discern a coherent attempt on his part to reconfigure the very terms of the debate on reason and revelation in medieval Islam. While past studies have either analyzed in depth or else summarized one or several of Ibn Taymiyya's arguments against the Universal Law, ${ }^{3}$ none has attempted to provide an overall account of them and to demonstrate the cumulative role they are meant to play at the heart of Ibn Taymiyya's magnum opus on reason and revelation in Islam.

\section{Ibn Taymiyya on the Universal Law and the variety of responses it has elicited}

In the year 606/1209, fifty-four years prior to the birth of Ibn Taymiyya, the great Persian Ash'arite theologian Fakhr al-Dīn al-Rāzī passed away, leaving behind a massive body of writings. Many of these writings were theological tracts aimed specifically at buttressing

3 See, e.g., Binyamin ABrahamov, "Ibn Taymiyya on the Agreement of Reason with Tradition," Muslim World, 82.3 (1992); Nicholas HEER, "The Priority of Reason in the Interpretation of Scripture: Ibn Taymīyah and the Mutakallimūn," in Literary Heritage of Classical Islam: Arabic and Islamic Studies in Honor of James A. Bellamy, ed. Mustansir Mir (in collab. with J. E. Fossum) (Princeton: Darwin Press, 1993); and Ovamir ANJuM, Politics, Law, and Community in Islamic Thought: The Taymiyyan Moment (New York: Cambridge University Press, 2012), 202-10 for general summaries. J. Yahya Міснот, "Vanités intellectuelles... L'impasse des rationalismes selon le Rejet de la contradiction d'Ibn Taymiyyah," Oriente Moderno, 19, no. 80 (2001) translates and analyzes Argument 9, while idem, "A Mamlūk Theologian's Commentary on Avicenna's Risāla Adhawiyya, being a translation of a part of the Dar' al-Ta'ärud of Ibn Taymiyya, with introduction, annotation, and appendices," Journal of Islamic Studies, 14.2 (2003) translates and analyzes a part of Argument 20. Nadjet ZougGAR, "Interprétation autorisée et interprétation proscrite selon le Livre du rejet de la contradiction entre raison et révélation de Taqī l-Dīn Aḥmad b. Taymiyya," Annales Islamologiques, 44 (2010) analyzes the introductory section of the Dar' ta'ärud as well as Argument 16, while idem, "Aspects de l'argumentation élaborée par Taqī l-Dīn Aḥmad b. Taymiyya (m. 728/1328) dans son livre du Rejet de la contradiction entre raison et Écriture (Dar' ta āruḍ al-'aql wa-l-naql)," Arabica, 61.1-2 (2014) examines Arguments 1 through 5. The most recent contribution is Frank GRIFFEL, "Ibn Taymiyya and His Ash'arite Opponents on Reason and Revelation: Similarities, Differences, and a Vicious Circle," The Muslim World, 108 (2018), which provides a useful, extensive presentation of al-Ghazālī’s and al-Rāzī’s elaboration of the Universal Law as an antecedent to Ibn Taymiyya's critique, while also summarizing and offering critical comments on this latter. Also relevant is M. Sait ÖZERVARLI, "The Qur'ānic Rational Theology of Ibn Taymiyya and his Criticism of the Mutakallimūn," in Ibn Taymiyya and His Times, ed. Yossef Rapoport and Shahab Ahmed (Oxford: Oxford University Press, 2010), 83-89. 
the position of the more textually conservative Ash'arite school of theology against the more rationalistically inclined Mu'tazilites. In one of his more influential theological treatises, Asās al-taqdīs, ${ }^{4}$ al-Rāzī enunciates a so-called "universal law," a statement representing a plea for truce on the part of Ash'arite theologians in the ongoing battle between reason and revelation. By al-Rāzī's time, this "universal law" had won the approving nod of the majority of his Ash'arite colleagues, whose school of thought was steadily becoming the standard, accepted formulation of Islamic theology in rationalistic terms throughout much of the Islamic domains. ${ }^{5}$

The Universal Law, as paraphrased by Ibn Taymiyya at the very beginning of the Dar ta ${ }^{\mathrm{a}} \mathrm{r} u d,{ }^{6}$ states:

If scriptural and rational indications, or revelation and reason, or the obvious outward meaning of the revealed texts and the definitive conclusions of rational thought - or other such ways of phrasing it - are in conflict, then either: (1) they must both be accepted, which is impossible as this would violate the law of noncontradiction [claiming both $p$ and $-p$ ]; (2) they must both be rejected, which is also impossible as this would violate the law of the excluded middle [claiming neither $p$ nor $-p$ ]; (3) precedence must be given to revelation, which is impossible since revelation is grounded in reason, such that if we were to give priority to the former over the latter [that is, to revelation over reason], this would amount to a rejection of both reason and [by extension] that which is grounded by reason [namely, revelation]. One must, therefore, (4) give precedence to reason over revelation, then either make figurative interpretation $\left(t a^{\prime} w \bar{l} l\right)$ of scripture [in accord with reason], or else negate the apparent meaning of scripture but refrain from assigning to it a definite, particular figurative interpretation (tafwīe $).{ }^{7}$

4 Fakhr al-Dīn Muhammad b. 'Umar al-RĀZī, Asās al-taqdīs, ed. Aḥmad Hijāzī al-Saqqā (Cairo: Maktabat al-Kulliyyāt al-Azhariyya, 1406/1986). Tariq Jaffer, in a recent monograph on al-Rāzī, points out that al-Rāzì himself refers to this work, which is devoted entirely to the question of $t a$ 'wìl, as " $T a$ 'sis altaqdīs," the title that is also listed for it in Hājjjī Khalīfa's Kashf al-zunūn. See Tariq JAFFER, Rāzīi: Master of Qur'änic Interpretation and Theological Reasoning (New York: Oxford University Press, 2015), 58-59, n. 19; (Muștạầ b. 'Abd Allāh) ḤĀJJī KHALĪFA, Kashf al-ẓunūn 'an asāmī al-kutub wa'lfunūn, ed. Muḥammad Sharaf al-Dīn Yāltaqāyā and Rif'at Bīlgeh al-Kilīsī, 2 vols. (Beirut: Dār Iḥyā̄ alTurāth al-'Arabī, [1360]/1941), I: 333.

5 For an overview of Ash'arite principles of interpretation ( $\left.t a^{\top} w \bar{l} l\right)$ from al-Juwaynī (d. 478/1085) to alJurjānī (d. 816/1413) when dealing with apparently conflicting rational and scriptural evidence, see HEER, "The Priority of Reason," 181-88.

6 See Taqī al-Dīn Aḥmad IBN TAYMIYYA, Dar' ta'ārud al-'aql wa'l-naql, aw Muwāfaqat șah̄ịh al-manqūl li-șarịh al-ma'qūl, ed. Muhammad Rashād Sālim, 11 vols. (Riyadh: Dār al-Kunūz al-Adabiyya, 1399/ 1979). For a discussion of antecedent statements of this Law in al-Ghazālī and al-Rāzī and the relationship of Ibn Taymiyya's paraphrase of the Law in the Dar' ta'ärud to these antecedents, see GRIFFEL, "Ibn Taymiyya and His Ash'arite Opponents," 15-30.

7 Cited at Dar', I: 4 See al-RĀZī, Asās al-taqdīs, 220-21. Al-Rāzī cites the same basic principle in similar

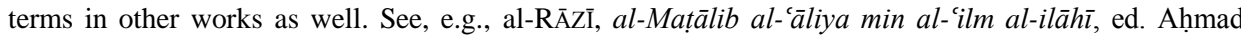
Hijāzī al-Saqqā, 9 vols. (Beirut: Dār al-Kitāb al-'Arabī, 1407/1987), IX: 116-17; idem, Muhașșal afkār al-mutaqaddimīn wa'l-muta'akhkhirīn min al-'ulamä' wa'l-hukamä' wa'l-mutakallimīn, ed. Țāhā 'Abd al-Ra'ūf Sa'd (Cairo: Maktabat al-Kulliyyāt al-Azhariyya, 1978[?]), 51; idem, Nihāyat al-'uqūl fì dirāyat

\footnotetext{
jais • 18 (2018): 63-85
} 
Ibn Taymiyya cites an alternative formulation of this law by al-Rāzī in another work, Nihāyat al-'uqūl fì dirāyat al-ușūl, where al-Rāzī adds a significant detail-central to Ibn Taymiyya's overall concern in the Dar' ta'ārud - namely, that "(the truth of) revelation can only be established through rational means, for it is only through reason that we can establish the existence of the Creator and know (the authenticity of) revelation." ${ }^{8}$ Ibn Taymiyya laments that al-Rāzī and his followers have made this into a "universal law" ( qānūn kullī) when interpreting scripture as it relates to God's attributes and other issues where they deem reason to be in contradiction with what scripture affirms. Some of themincluding al-Rāzī himself - add to this the notion that scriptural indicants or proofs (adilla samiyya) are, in fact, inherently incapable of engendering certainty and therefore cannot be relied upon in matters of religious knowledge. ${ }^{9}$ Others before them, Ibn Taymiyya tells us,

al-ușūl, ed. Sa'īd 'Abd al-Lațīf Fūda, 4 vols. (Beirut: Dār al-Dhakhā’ir, 1436/2015), I: 143; idem, alArba'in fì uṣūl al-dīn, ed. Aḥmad Hijāāī al-Saqqā, 2 vols. (Cairo: Maktabat al-Kulliyyāt al-Azhariyya, 1406/1986), I: 163-64; idem, al-Masā̉il al-khamsūn fí uṣūl al-dīn, ed. Aḥmad Hijāzīi al-Saqqā (Beirut: Dār al-Jīl; Cairo: al-Maktab al-Thaqāfī, 1410/1990), 39-40; idem, Ma ālim ușūl al-dīn, ed. Țāhā 'Abd al-Ra'ūf Sacd (Beirut: Dār al-Kitāb al-'Arabī, 1404), 48; and idem, Mafātīh al-ghayb (al-Tafsìr al-kabìr), 32 vols. (Beirut: Dār al-Fikr, 1401/1981), XXII: 6-7. See HEER, “The Priority of Reason,” 184-85 for an English translation and discussion of the passages cited here in al-Rāzī's Asās al-taqdīs and al-Masä ${ }^{\prime} i$ al-khamsūn and JAFFER, Rāzī, 89-94 for a translation and discussion of these same two passages, as well as the passage cited here from Mafätīh al-ghayb. On the notion of tafwìld, or "consigning the meaning [of problematic scriptural passages] to God" and not proffering a specific figurative interpretation thereof, see Binyamin ABRAHAMOV, "The 'Bi-lā Kayfa' Doctrine and Its Foundations in Islamic Theology," Arabica, 42.3 (1995). On the Universal Law, see also Rodrigo ADEM, "The Intellectual Genealogy of Ibn Taymīya" (Ph.D. dissertation, University of Chicago, 2015), 210-29.

8 Cited at Dar', v: 330-31. See al-RĀZĪ, Nihāyat al- 'uqūl, I: 143 and similar at idem, al-Masā̉il alkhamsūn, 39-40. For statements by other major Ash'arite theologians to the effect that reason is the only means by which the authority of scripture can be established, see, e.g., 'Abd al-Qāhir al-BAGHDĀDĪ, Kitāb Ușūl al-dīn (Istanbul: Mațba at al-Dawla, 1346/1928), 23; Imām al-Haramayn al-JUWAYNī, Kitāb al-Irshād ilà qawātịi al-adilla fì uṣūl al-i'tiqād, ed. Muhammad Yūsuf Mūsà and 'Alī 'Abd al-Mun'im 'Abd al-Ḥamīd (Cairo: Maktabat al-Khānjī, 1369/1950), 358-60; and Abū Ḥāmid al-GHAZĀLĪ, alIqtișād fí 'l-i'tiqād, ed. 'Abd Allāh Muhammad al-Khalīlī (Beirut: Dār al-Kutub al-'Ilmiyya, 1424/2004), 115. For English translations of the passages cited here from al-Juwayn̄̄’s Irshād and al-Ghazālī's Iqtișād, see HEER, "The Priority of Reason," 185-86. For a more extensive list of sources-including for the later Ash'arites Shams al-Dīn al-Iṣfahānī (d. 749/1348), Saćd al-Dīn al-Taftāzānī (d. 792/1390), and al-Sharīf al-Jurjānī (d. 816/1413), as well as for Mu'tazilites who also held this doctrine-see ibid., 19394, n. 21 and 194, n. 22.

9 See, for example, Dar’, v: 335, where Ibn Taymiyya cites a passage from al-Rāzì’s Nihāyat al-'uqūl, a few pages after his statement of the Universal Law cited above, to the effect that "scriptural indicants cannot be relied upon in matters of (certain) knowledge (al-adilla al-naqliyya lā yajūzu 'l-tamassuk bihā fì 'l-masā’il al-'ilmiyya)." See al-RĀZī, Nihāyat al-'uqūl, I: 146 (where, however, al-Rāzī has "almasā’il al-'aqliyya," not "al-masā’il al-'ilmiyya"); idem, Ma'ālim, 25; idem, Muhașșal, 51; and idem, Arba'in, II: 253-54 (where, however, al-Rāzī does state that scriptural indicants can yield certainty if backed up by mutawātir reports; see similar at idem, Mațāilib, IX: 117). For further discussion, see Carl Sharif El-ToBguI, "The Hermeneutics of Fakhr al-Dīn al-Rāzī," in Coming to Terms with the Qur'ān: A volume in honor of Professor Issa Boullata, McGill University, ed. Khaleel Mohammed and Andrew Rippin (North Haledon, New Jersey: Islamic Publications International, 2008), 139-40 and, more extensively, JAFFER, $R \bar{a} z \bar{\imath}, 77-83,102-4$. Notwithstanding al-Rāzī's qualification in Arba īn concerning the ability of scriptural indicants to yield certain knowledge if corroborated by tawätur, Jaffer concludes - primarily on the basis of Asās, Mafātịh al-ghayb, and Ma'ālim — that al-Rāzì fundamentally 
had already articulated this "universal law," such as al-Ghazālī (d. 505/1111), who employed it in his short treatise Qānūn al-ta'will ${ }^{10}$ in answering questions posed to him by students of his such as Abū Bakr b. al- ${ }^{\circ} A r a b \overline{1}$ (d. 543/1148). This latter articulated an alternative formulation of the law in a lengthy work also with the same title ${ }^{11}$ based on the method followed by al-Ghazālī's teacher, al-Juwaynī (d. 478/1085), ${ }^{12}$ as well as those before him, such as al-Bāqillānī (d. 403/1013). ${ }^{13}$ In sum, Ibn Taymiyya explains, the

denies the ability even of mutawätir reports to yield certitude (see ibid., 80-83), thus assigning "even the strongest of hadìth reports a low epistemic value" (ibid., 82). [These conclusions thus concur with the earlier findings of Ignaz GOLDZIHER, "Aus der Theologie des Fachr al-dīn al-Rāzī," Der Islam, 3 (1912): 230-37 and Roger ARNALDEZ, "L'œuvre de Fakhr al-Dīn al-Rāzī : commentateur du Coran et philosophe," Cahiers de civilisation médiévale, $X^{e}$-XII siècles, 3 (1960): 315.] Jaffer reports further that the radicalness of al-Rāzì's skepticism vis-à-vis hadīth reports was matched only by the "maverick Mu'tazilite" Abū Isḥāq al-Nažzām (d. c. 221/836), the "only thinker who expresses such a degree of doubt about prophetic reports" and whose "views were considered radical even by Mu'tazilite standards." JAFFER, $R \bar{a} z \bar{\imath}, 81$, n. 71 and 83, n. 77. Van Ess credits Ibn Taymiyya with having possessed a "well-informed insight" into the discussions that had taken place regarding the probity and proof value of scriptural indicants, specifically in his al-Furqān bayn al-haqq wa'l-bätill. Ibn Taymiyya, he tells us, knew that al-Rāzī was among those who "polemicized most strongly against scriptural proofs," which he held to be fundamentally inconclusive. See Josef VAN Ess, Die Erkenntnislehre des 'Adudaddīn alİcī: Übersetzung und Kommentar des ersten Buches seiner Mawāqif (Wiesbaden: Franz Steiner Verlag, 1966), 409. On these grounds, van Ess likewise characterizes al-Rāzī’s position as "an extreme case" ('ein Extremfall'). Ibid., 410

10 Al-GHAZĀLĪ, Qānūn al-ta’wīl, ed. Maḥmūd Bījū (n.p., 1413/1992), 19, 21. Related discussions can be found at idem, Iqtișād, 116 and idem, Fayșal al-tafriqa bayna 'l-Islām wa'l-zandaqa, ed. Mạ̣mūd Bījū (Istanbul[?]: Dār al-Bayrūtī, 1413/1993), 47-48. [For a translation and introduction to this work, see Sherman A. JACKSON, On the Boundaries of Theological Tolerance in Islam: Abū Hāmid al-Ghazālī's Fayșal al-Tafriqa (Oxford: Oxford University Press, 2002).] For an analysis of al-Ghazālī's approach to metaphorical interpretation, see Frank GRIFFEL, Al-Ghazālì's Philosophical Theology (Oxford: Oxford University Press, 2009), 111-22, esp. 111-16 and, more expansively, idem, "Al-Ghazālī at His Most Rationalist: The Universal Rule for Allegorically Interpreting Revelation (al-Qānūn al-Kulli fi $t$ Ta'wīl)," in Islam and Rationality: The Impact of al-Ghazälī. Papers Collected on His 900th Anniversary. Volume 1, ed. Georges Tamer (Leiden: Brill, 2015). For a translation of al-Ghazālī's Qānūn alta'will, see Nicholas HEER, "Al-Ghazali: The Canons of Ta'wil," in Windows on the House of Islam: Muslim Sources on Spirituality and the Religious Life, ed. John Renard (Berkeley: University of California Press, 1998).

11 See al-Qāọ̄i Abū Bakr IBN AL-'ARABī, Qānūn al-ta’wīl, ed. Muḥammad al-Sulaymānī (Jeddah: Dār alQibla li'l-Thaqāfa al-Islāmiyya, 1406/1986), 646-47. See also idem, al-'Awāṣim min al-qawāṣim, ed. 'Ammār Ṭālibī (Cairo: Maktabat Dār al-Turāth, 1394/1974), 231.

12 See, for instance, al-JUWAYNī, Irshād, 358-60.

13 See, for instance, Abū Bakr Muḥammad b. al-Ṭayyib al-BĀQILlānī, Kitāb al-Tamhīd, ed. Richard Joseph McCarthy (Beirut: al-Maktaba al-Sharqiyya, 1957), 259, where we read that "it is necessary to divert speech from its apparent meaning if rational and scriptural indicants rule out its being used in accordance with the primary sense" (innamā yajibu șarf al-kalām 'an żăhirihi idhā kānat dalä’il al-'aql wa'l-sam' tamna'u istímālahu 'alà mā warada bihi). Ibn Taymiyya in general thinks very highly of alBāqillānī, no doubt since he was close in time to al-Ash'arī and therefore still recognizably part of the old-school Ash'arīs, or "mutaqaddimūn" (with al-Juwaynī seen as the bridge over to the later doctrine).

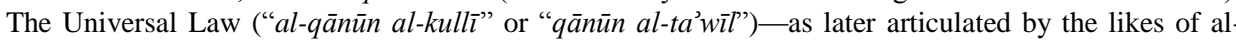
Juwayn̄̄, al-Ghazālī, and al-Rāzī — does not appear in explicitly crystallized form in al-Bāqillān̄i, though the idea and principle of $t a^{\prime} w \bar{l} l$ are present (as in the quote from K. al-Tamhìd above). See the comments of Muḥammad Sulaymān (editor) at Abū Bakr IBN AL-'ARABī, Qānūn al-ta’wīl, 246.

jais 18 (2018): 63-85 
adherents of every doctrine have established for their school an analogous rule: they take as true and objective knowledge that which they deem reason has come to know, then subordinate revelation to this alleged "knowledge" and (re)interpret it accordingly.

Such reinterpretation of scripture as prescribed by the Universal Law has conventionally been carried out in one of two principal ways: either through figurative interpretation $\left(t a^{\prime} w \bar{l} l\right)$, normally defined as assigning to a revealed text a meaning other than its overt or obvious (zāhir) sense in accordance with a conclusion reached through reason, or through suspension of meaning (tafwi $\bar{c}$ ), normally defined as declaring the obvious meaning invalid but refraining from providing any specific alternative interpretation, conferring ("tafwīẹ") its true meaning unto God.

\section{Specious rationality and its discontents: Reason in a cul-de-sac ${ }^{14}$}

Ibn Taymiyya begins his case against the Universal Law by observing that the principle according to which a person should give precedence to the deliverances of his own rational faculty over the obvious meaning of the revealed texts is a position not governed by a universally applicable rule ( $q a w l$ la yandabiț), since each kalām theologian or philosopher-all of whom are in dispute with each other over what they call "rational knowledge" - claims that he knows by rational necessity, or through the process of rational investigation, a fact whose opposite his contender claims also to be known by necessity or through rational investigation. For instance, both those who negate (some of) the Divine Attributes and the Divine Decree (qadar) - Ibn Taymiyya singles out here the Mu'tazila and those who have followed them from among the Shīites - as well as those who affirm these claim to do so on the basis of allegedly conclusive rational arguments.

Moreover-and this is a cardinal tenet of Ibn Taymiyya's doctrine on reason and revelation - the further a school of thought is from the Sunna, ${ }^{15}$ the greater is the internal disagreement among its adherents as to what the dictates of reason actually are. This point is essential. For Ibn Taymiyya, reason and revelation coincide in a very fundamental sense, with the natural result that the more a faction moves away from what reason and revelation essentially overlap in affirming, the more that faction experiences internal dissention, divergence of opinion, and incoherence in terms of rationality itself, in addition to finding

14 Based on Argument 9 (Dar', I: 156-70).

15 Ibn Taymiyya's use of the term "Sunna" is perhaps closest to the Greek-derived English term "orthodoxy," literally "correct belief." I shall retain, however, Ibn Taymiyya's original term, since it renders more transparent precisely what "correct belief" is for our author and how it is to be determined. Whereas "orthodoxy" normally implies a body of doctrine backed up by the ecclesiastical authority of an institutional church - an institution that has no direct equivalent in Islam - "correct belief" for Ibn Taymiyya is synonymous with the beliefs and practices of the first three generations (qurūn) of Muslims - that of the Companions (șahāba), the Successors (tāabi $\left.{ }^{\complement} \bar{u} n\right)$, and the Successors of the Successors ( $t \bar{a} b i^{\complement} \bar{u}$ al-tābi $i \bar{l} n$ _ _ particularly the very first generation comprised of the Prophet's own contemporaries. As we shall discover, Ibn Taymiyya's insistence that sound reason and authentic revelation always concur and never contradict entails, as a corollary, that the first generations were in possession simultaneously of a uniquely normative - and hence quintessentially orthodox — understanding of sacred scripture and of the soundest rational methods for reasoning about matters divine. 
itself at increasingly greater odds with revelation. In other words, one is either fully in line with both pure reason ('aql șarīh) and an essentially straightforward reading of authenticated revelation (naql șahīh), or one drifts away from both reason and revelation together and ends up not only contradicting revelation and explaining it away through an increasingly liberal application of the principle of $t a^{\prime} w \bar{l} l$, but also falling prey to increasingly intractable rational contradictions, divergences, and improbabilities at the same time. ${ }^{16}$

This principle can best be illustrated in the form of the following "Taymiyyan pyramid":

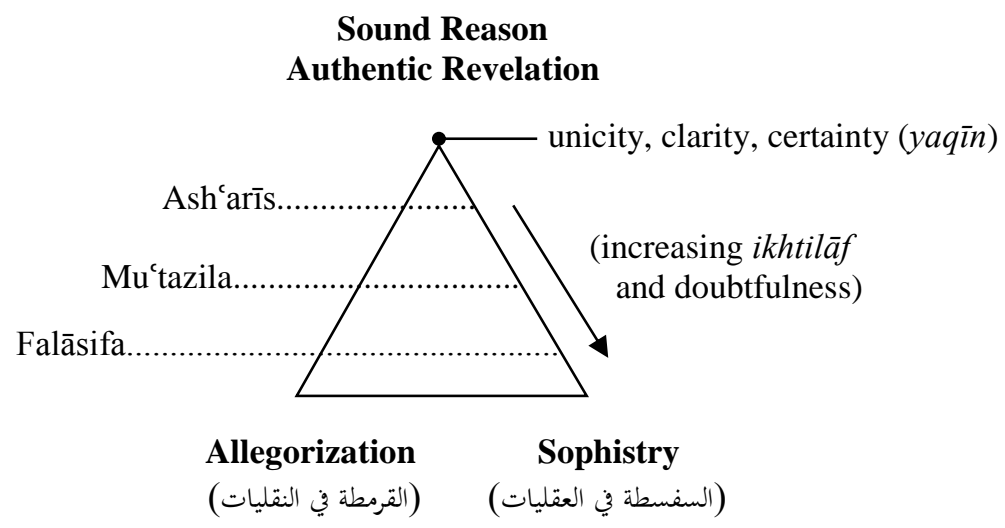

Truth is that point of unicity, clarity, and certainty (yaqin) at which the testimony of sound reason and that of authentic revelation are fully concordant. According to the pyramid, the Mu'tazila, for example, exhibit greater internal discord than the "affirmationists" (muthbitūn) among the kalām theologians such as the Ash'arīs, as evidenced by the extent of disagreement between the Mu'tazilite school of Basra and that of Baghdad - though adherents of the former, Ibn Taymiyya tells us, are closer to the Sunna (i.e., to "orthodoxy") than the latter and are therefore more internally united than their rivals from Baghdad. The Shīa evidence even greater internal discord than the Mutazila, since they are even further removed from sunnaic orthodoxy. As for the philosophers, Ibn Taymiyya chides, it is almost impossible to find anything upon which they collectively agree. In point of fact, their internal divergences and differences are greater than those that separate from each other the three different religious communities of Muslims, Jews, and Christians. ${ }^{17}$ Indeed, says Ibn Taymiyya, their differences concerning astronomy alone-which is an arithmetic, mathematical subject that figures among the most objective and accurate of their sciences-

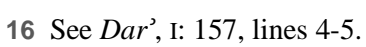

17 Ibn Taymiyya is apparently referring here not to the internal divergences within each confessional community, but rather saying that the divergences and differences that separate the three communities from each other are still less than those that divide the philosophers against each other, in other words, that Muslims, Jews, and Christians - despite the (often fundamental) differences which separate themare nevertheless in agreement with each other on a considerably greater number of issues than are the philosophers, all of whom claim, despite their wild divergences of opinion, to have arrived at the various doctrines they hold through pure reason on the basis of rationally demonstrable and unimpeachable proofs and arguments.

jais • 18 (2018): 63-85 
are greater than the differences among any of the various sects of Muslims. As for metaphysics, the leading philosophers themselves aver that they are unable to reach any kind of certitude with respect to it whatsoever. Rather, their discourse on metaphysical matters reduces to little more than hazarding judgements of likelihood and the weighing of probabilities. ${ }^{18}$

To underline the specious nature of much of kalām discourse, Ibn Taymiyya appeals to several of the major rational theoreticians (nuzzāar) themselves in witness of the futility of their life-long efforts to attain theological certainty through the practice of dialectical theology. We read, for example, the following two lines by 'Abd al-Karīm al-Shahrastānī (d. 548/1153) emphasizing how such theoreticians often ended up with nothing but confusion and perplexity:

I have made the rounds of the gatherings of the learned

And cast my eyes upon the haunts of erudition;

Yet never did I see but men perplexed, with their chins in their hands

Or gnashing their teeth in regret. ${ }^{19}$

Ibn Taymiyya also cites nine lines of similar import from Ibn Abī al-Hadīd (d. 656/1258), "one of the foremost Shī ite thinkers with Mu'tazilite and philosophical leanings." ${ }^{20} \mathrm{He}$ also points out that the illustrious latter-day Ash'arite theologian and legal scholar Sayf al-Dīn al-Āmidī (d. 631/1233) in most of his books suspends judgement on many of the central issues of theology, declaring spurious the arguments of various sects but remaining in the end perplexed and unable to take a position himself. ${ }^{21}$ Similar is the case of the celebrated $7^{\text {th }} / 13^{\text {th }}$-century logician and judge of Persian origin Abū 'Abd Allāh Afḍal al-Dīn alKhūnajī (d. 646/1248), best known for his logical treatise Kashf al-asrār 'an ghawāmiḍ al$a f k \bar{a} r,{ }^{22}$ who was reported to have said on his deathbed: "I die having learned nothing but

18 Ibid., I: 156, line 4 - 159, line 5. Ibn Taymiyya refers his reader to a number of sources to back up his point regarding the disarray of the philosophers, including al-Ash'arī’s Maqālāt ghayr al-Islämiyyīn and al-Bāqillānī's Daqā̄iq al-haqā̉iq, both of which, he explains, contain many times more in the way of the disputes and differences among the philosophers than al-Shahrastānī (in his Kitāb al-Milal wa'lnihal) and others have mentioned. Al-Bāqillānī’s Daqā̉iq is, unfortunately, lost. (See editor's note at ibid., I: 6, n. 3.)

19 "la-qad țuftu fī tilka 'l-ma'āhidi kullihā, wa-sayyartu țarfì bayna tilka 'l-macālimi / fa-lam ara illā wāḍi an kaffa hā̄irin, 'alà dhaqanin aw qāri'an sinna nādimi." Ibid., I: 159, lines 7-11. M. Sālim, the editor of the $\operatorname{Dar}^{\prime} \operatorname{ta}^{\prime} \bar{a} r u d$, also cites (at ibid., I: 159, n. 2) a two-line response to al-Shahrastāni by the latter-day Yemeni scholar Muhammad b. Ismā̄īl al-Amīr al-Șanāān̄ (d. 1182/1768), who retorted: "lacallaka ahmalta 'l-ṭawāfa bi-machadi 'l-Rasūli wa-man lāqāhu min kulli ‘ālimi / fa-mā hāāa man yuhdà bi-hadyi Muhammadin, wa-lasta tarāhu qāri'an sinna nādimi":

Perhaps your rounds have missed the learned circle of the Prophet, And every man of knowledge who encountered him;

For he who is led by the guidance of Muhammad is never perplexed, Nor ever found gnashing his teeth in regret.

20 Ibid., I: 161.

21 Ibid., I: 162, lines 3-4.

22 See Afḍal al-Dīn al-KHŪNAJī, Kashf al-asrār 'an ghawāmiḍ al-afkār, ed. Khaled El-Rouayheb (Tehran: Iranian Institute of Philosophy; Berlin: Institute of Islamic Studies, Free University of Berlin, 2010). 
that the possible is dependent upon the impossible (al-mumkin muftaqir ilà 'l-mumtani); yet dependency (iftiqār) is a negative property, thus I die having learned nothing at all." 23

Ibn Taymiyya contrasts the drastic agnostic pessimism expressed in the numerous quotations above with what he describes as the calm assuredness of those who know and who cling resolutely to the "original, pristine, orthodox, scripturally revealed prophetic method." 24 Such men are thoroughly familiar both with this method and with the doctrines that are claimed to be in contradiction with revelation - such as the claim of the createdness of the Qur'ān or the purely symbolic nature of the Divine Attributes-whereupon they can easily recognize the invalidity of such doctrines by virtue of the deliverances of what Ibn Taymiyya calls "pure natural reason" (al-ma'qūl al-șarịh), which is always found to be in full conformity with what is affirmed by authentic revelation (al-manqūl al-șah̄hh). However, those who delve into the elements of philosophy and discursive theology said to contradict revelation without possessing full knowledge of the contents and various concomitant implications (lawāzim) of the revealed texts, as well as of the doctrines alleged to be at odds with them, are unable to arrive at any certain knowledge in which they can feel confident, but rather end up in confusion and perplexity. The most preeminent of them are even at a loss to provide fully conclusive arguments for the existence of the Creator Himself, a topic of central concern to Ibn Taymiyya in the Dar' ta'a $r u d$ which merits a separate study on its own. Some, he says, end up in contradiction, like al-Rāzī, while others are forced to suspend judgement on the matter, like al-Āmidī. Indeed, such thinkers often mention a number of positions of various schools, claiming that truth lies in one or the other of them (though without necessarily being able to determine which one), while all the various positions mentioned, declares Ibn Taymiyya confidently, can in fact be demonstrated on the basis of pure natural reason to be false and without rational foundation. ${ }^{25}$

\section{Ibn Taymiyya's project: Refuting the Universal Law}

If, as Ibn Taymiyya sees it, the rational processes at work have led to such an abusive "interpretation" of scripture and simultaneously to a rational cul-de-sac in which reason itself breaks down, then wherein does he think a solution could lie? This is the question to which Ibn Taymiyya has dedicated the entirety of his magnum opus and which shall occupy us in the remainder of this article. Ibn Taymiyya's project in the Dar' ta $^{\text {'a }} r u d$, at its most essential, consists in undermining and refuting the very Universal Law itself, along with the premises and assumptions it takes for granted, since he considers this Law the primary culprit in having brought about the intellectual and religious disorder he inherited at the turn of the eighth Islamic century. It bears stressing that, for Ibn Taymiyya, the project of

23 Dar', I: 162, lines 4-7. Cited also in Taqī al-Dīn Aḥmad IBN TAYMIYYA, Kitāb al-Radd 'alà 'l-manțiqiyyīn, al-musammà ayḍan Nașīhat ahl al-īmān fì 'l-radd 'alà manțiq al-Yūnān, ed. 'Abd al-Ṣamad Sharaf al-Dīn al-Kutubī (Beirut: Mu'assasat al-Rayyān, 1426/2005), 114, as well as in Jalāl al-Dīn alSUYŪṬī's (d. 911/1505) abridgement of this work, Jahd al-qarīha fì tajrīd al-Nașịha. See Wael B. HALLAQ, Ibn Taymiyya against the Greek Logicians (Oxford: Oxford University Press, 1993), 42.

24 "al-țarīqa al-nabawiyya al-sunniyya al-salafiyya al-Muhammadiyya al-shar'iyya." Dar', I: 164, line 1. 25 See ibid., I: 164.

jais • 18 (2018): 63-85 
undoing the Universal Law is imperative in order not only to salvage the integrity of revelation but to rescue reason as well, as both have been, in his view-and as schematized in the Taymiyyan pyramid above (p. 70) — dangerously compromised primarily by a faulty and abusive use of the rational faculty that he seeks to redress and rehabilitate - to the ultimate benefit of both revelation and reason.

In order to refute the Universal Law, Ibn Taymiyya puts forth no fewer than thirtyeight $^{26}$ arguments (wujūh, sing. wajh, ${ }^{27}$ lit., "aspects" [of incoherence]), located primarily in Volumes I and V of the Dar' ta'a logically unsound and, therefore, theoretically baseless. As is typical of the writings of Ibn Taymiyya, a number of these thirty-eight arguments overlap with each other, some seemingly forming an expanded or summarized version of others. Furthermore, the arguments as Ibn Taymiyya has presented them do not follow any specific logical order, but rather are given one after the other as so many discrete objections to the Universal Law. For the purposes of the presentation below, therefore, rather than simply listing the arguments in the order in which Ibn Taymiyya has presented them, I have grouped them by theme and argument, paraphrasing in each of the following sections a coterie of arguments that share a unifying theme or that seem intended by their author to accomplish a common objective. The following sections cover specific criticisms meant to accomplish three identifiable discrete goals and to shift the inherited paradigm of reason and revelation in three distinct ways.

\section{On reason "grounding" our knowledge of revelation ${ }^{28}$}

Ibn Taymiyya endeavors to undermine the Universal Law's main premise, namely, that if precedence be given to revelation over reason, this would amount to a rejection of the very thing that grounds it - namely, reason — which would fatally undercut revelation itself. By "grounding" here is meant that reason is the basis on which rests our knowledge of the truth and validity of revelation; that is, reason is said to ground revelation not ontologically, but epistemologically.

26 Ostensibly forty-four, but see explanation at n. 2 above.

27 Tariq Jaffer discusses al-Rāzī’s use of the wajh (translated as "viewpoint" or "argument") which, in addition to the mas'ala (which he renders as "question" or "point of investigation"), lies at the center of his dialectical method - a method which the philologist, littérateur, and biographer Ṣalāh al-Dīn b. Aybak al-Ṣafadī (d. 764/1363) characterizes as unprecedented. Jaffer explains that al-Rāzī uses the wajh both to corroborate and to critique philosophical arguments, and as a vehicle for recording and resolving the shubuhāt, or objections/counterarguments, raised against a given position. See JAFFER, Rāzi, 27-29. On the "dialectal turn" that occurred in during the $12^{\text {th }} / 6^{\text {th }}$ century, see Frank GRIFFEL, "Between alGhazālī and Abū 1-Barakāt al-Baghdādī: The Dialectical Turn in the Philosophy of Iraq and Iran During the Sixth/Twelfth Century," in In the Age of Averroes: Arabic Philosophy in the Sixth/Twelfth Century, ed. Peter Adamson (London: The Warburg Institute, School of Advanced Study, University of London, 2011).

28 The question of the manner in which revelation is "grounded" in reason is taken up primarily in Arguments 3 (Dar', I: 87-133), 24 (V: 214-16), and 29 (V: 268-86). 
Ibn Taymiyya begins by challenging the philosophers' and theologians' notion of precisely what is implied by our knowledge of revelation being "grounded" in reason. "We do not concede," he tells us, "that if precedence be given to revelation, this would amount to impugning the very thing which grounds it, namely, reason." 29 This is so, he explains, for if it is the knowledge that we acquire through reason that constitutes the epistemological grounding upon which our knowledge of the truth and validity of revelation rests, it is nevertheless the case that not everything known (or thought to be known) through reason figures among that rational knowledge which authenticates revelation. The various objects of knowledge apprehended through reason are innumerable, and knowledge of the validity and truth of revelation is contingent, at most, upon that by which the veracity of the Prophet Muhammad and his prophetic mission can be determined. Relevant (rational) knowledge here would be, for example, proof of the existence of God and His vindication of the truthfulness of the Prophet through miracles, and the like. ${ }^{30}$ The principal error of those who call for adherence to the Universal Law, he explains, is that they make all forms of rationally grounded knowledge one category with respect to validity and invalidity, whereas a positive judgement regarding the validity of revelation, as we have seen, merely requires the validity of that part of rationally grounded knowledge concomitant (muläzim) to it, not the validity of that part which runs counter to or negates (yunäfi) it. ${ }^{31}$

Ibn Taymiyya tells us further that those who have formulated and instituted (alwā di $^{\mathrm{c}} \bar{u} n a$ li-) the Universal Law, such as al-Ghazālī, al-Rāzī, and others, themselves concede that our knowledge of the Prophet's veracity is not contingent upon any putative

29 Dar’, I: 87, lines 12-13.

30 It is significant that Ibn Taymiyya explicitly classifies knowledge of the existence of God, the reality of prophecy, and the possibility of miracles all as propositions subject to verification through the use of reason. In other words, he agrees that revelation $i s$, in a fundamental manner, grounded in reason, for it is by reason alone that we can test and confirm the most basic claims of revelation, that without which scriptural revealed religion would simply have no plausibility to begin with. (GRIFFEL, "Ibn Taymiyya and His Ash'arite Opponents," 36-37, has recently come to a similar conclusion.) These findings, further elaborated throughout the rest of the current section, thus correct Nicholas Heer's contention that "as a Hanbalite traditionalist Ibn Taymìyah held firmly to the position that scripture was in no way dependent on rational arguments, either for the establishment of its truth or for an explanation of its meaning..." (HEER, "The Priority of Reason," 191-92). In an earlier passage Heer remarks: "Scripture, he claims, does not have to be proven true through the use of reason, as the theologians assert, because it itself contains all the arguments necessary to support its principal doctrines." Ibid., 188. The point that Heer seems to miss here is that, according to Ibn Taymiyya, scripture does indeed rely on argumentsrational arguments, naturally - to support its principal doctrines. This amounts to an admission that reason is indeed necessary in establishing the authenticity and plausibility of scripture, a point that Ibn Taymiyya, as will become clear throughout our treatment, fully concedes. In fact, he makes much of the fact that scripture includes and advances rational arguments, trying to capture the rational "high ground" for revelation away from the philosophers and mutakallimūn. Indeed, it would be important for a separate study to examine in depth Ibn Taymiyya's own rational proofs for the existence of God and the possibility of miracles in contrast to those of the theologians and philosophers and, in doing so, to define precisely what it is he means by that "reason" which is capable of doing so in a manner definitive enough to lend the fundamental claims of scripture a baseline of rational plausibility. A detailed analysis of such proofs, however, lies beyond the scope of the current article.

31 “wa-ma'lūm anna 'l-sam innamā yastalzimu șị̣hat ba ḍ̣hā 'l-mulāzim lahu lā șiḥhat al-ba'ḍ al-munāfĩ lahu." Dar', I: 91, lines 4-5.

jais • 18 (2018): 63-85 
rational conclusions that are at odds with revelation. In fact, a great number of them, including al-Ghazālī himself, in addition to al-Shahrastān̄̄, al-Rāghib al-Iṣfahān̄i (d. 502/1108-9), and others, hold knowledge of the existence of God to be inborn, necessary knowledge (fitrī darūrī). ${ }^{32}$ In addition, Ibn Taymiyya maintains, revelation is itself replete with rational arguments for the existence and almightiness of the Creator and His corroboration, through miracles and signs, of the veracity of His messenger. Not only does that which revelation affirms of these matters not contradict, but rather congrues with (yuwäfiq), the rational foundations on the basis of which we come to know the authenticity of revelation, but indeed revelation itself, according to Ibn Taymiyya, provides far more numerous - and, we are to understand, far more evincive-rational arguments for such matters than we find in the books of the rational theoreticians themselves. Even the majority of those who hold knowledge of the Creator to come about only through deliberate reflection (nazar) — as opposed to instinctively (bi'l-fitra) — concede, critically, that of the various inferential methods available for arriving at knowledge of the authenticity of the Prophet Muhammad's claim to prophethood, there indeed exist such as do not contradict anything affirmed in the texts of revelation. ${ }^{33}$

In establishing this point, ${ }^{34}$ Ibn Taymiyya reverses the Universal Law to show that the opposite principle - that is, prioritizing revelation over reason in any case of conflict - can be argued and defended in an exactly analogous manner, with the implied conclusion that if it is rationally incoherent either to put reason above revelation or to put revelation above reason, then the truth (which is always and intrinsically coherent) must lie in the fact that there can be no bona fide contradiction between these two sources of knowledge, the precise point Ibn Taymiyya is concerned to prove in the Dar' $\operatorname{ta}^{`} \bar{a} r u d$. The opposite rule would state:

If reason and revelation contradict, then revelation must be given priority over reason, since reason has adjudged revelation veracious in everything it contains, whereas revelation has not judged reason to be correct in all the various conclusions to which it might come, nor is our knowledge of the authenticity of revelation

32 See, e.g., Muhammad b. 'Abd al-Karīm al-SHAHRASTĀNī, Kitāb Nihāyat al-iqdām fì 'ilm al-kalām, ed. Alfred Guillaume (Cairo: Maktabat al-Thaqāfa al-Dīniyya, 1430/2009), 118-19.

33 Al-Rāzī himself, Ibn Taymiyya informs us, is one of those who concur, as is evidenced by his discussion of takfír in his Nihäyat al-'uqül, where he concludes that "it has been established that the knowledge of the principles $(u s \underline{u} l$ ) upon the validity of which depends (our knowledge of the authenticity of) the messengership of Muhammad (may God bless him and grant him peace) is patent and evident knowledge ('ilm jali zähir), and scholars have only discussed these principles on account of their responsibility to remove the doubts raised by those who would seek to invalidate them (almubțilün). (Otherwise), it is firmly established that the foundations of Islam are patent and clear, and that the proofs which establish them are mentioned in a comprehensive manner ('alà 'l-istiqsa $\vec{a}^{\prime}$ ) in the Book of God, free of anything erroneously imagined to oppose them." Dar', I: 96, lines 5-10. Al-RĀZī, Nihāyat al-'uqūl, IV: 290-91. For Ibn Taymiyya's full citation of al-Rāzī's discussion of takfìr in his Nihāyat al-'uqūl, see Dar', I: 93, line 6-96, line 10.

34 See Argument 6 (Dar', I: 138-44). 
dependent upon (mawqūf 'alà) all of the several conclusions at which reason may have arrived. ${ }^{35}$

This position, says Ibn Taymiyya, is better advised (awjah) than the previous position of granting a blanket priority to reason over revelation, since reason indicates the truth of revelation in a general and unrestricted sense (dalāla 'āmma muțlaqa). This is especially true, Ibn Taymiyya elaborates, as the disparity between a prophet, on the one hand, and the most intelligent and knowledgeable of ordinary men, on the other, is manifestly greater than the disparity between, say, the master craftsmen of various trades and ordinary folk unschooled in the same trades. In fact, the difference involved is no less than a categorical one, since theoretically any ordinary man could, by dint of sustained personal effort, attain masterly knowledge of a given field, whereas prophethood is not to be attained through personal striving, but rather is only bestowed by God upon those whom He has elected. ${ }^{36}$

In summary, Ibn Taymiyya endeavors through the set of arguments presented above to undermine the Universal Law's main premise, namely, that if precedence be given to revelation over reason, this would amount to a rejection of the very thing that grounds revelation - namely, reason - thereby fatally undercutting revelation itself. Ibn Taymiyya challenges the philosophers' and theologians' notion of what it means for our knowledge of revelation to be grounded in reason by arguing, in essence, that what we call reason does not, as many fancy, constitute one undifferentiated category, such that impugning any of the various conclusions reason is thought to have reached would amount to undermining all of them. Rather, he contends, the various discrete conclusions reached through the rational faculty are innumerable, and our knowledge of the validity of revelation is contingent, at most, upon only those discrete elements of rational judgement by which, for example, we may ascertain the veracity of the Prophet Muhammad and the authenticity of his prophetic mission. If this be the case, then imprecating other distinct conclusions of reason (such as those that contradict certain discrete assertions of scripture) does not, as most theologians and philosophers held, automatically undermine our confidence in the very rational faculty itself and each one of its sundry conclusions, not least of which the rational basis by virtue of which we have concluded the authenticity of revelation.

35 Ibid., I: 138, lines 1-3.

36 Ibn Taymiyya is citing here the orthodox theological position on the purely God-given and "nonacquired" nature of the prophetic office, as opposed to the faläsifa's interpretation of prophethood as an essentially natural faculty analogous to the bursts of inspiration from beyond that may result from the personal spiritual efforts of a practicing sage or mystic. For more on various conceptions of prophethood in Islam, see Fazlur RAHMAN, Prophecy in Islam: Philosophy and Orthodoxy (New York: Routledge, 2008).

jais • 18 (2018): 63-85 


\section{Knowledge vs. conjecture: Conclusiveness is what counts ${ }^{37}$}

The refutation of the Universal Law, Ibn Taymiyya declares, consists in showing the falseness of its premises. The Law, as enumerated in Section II above, is based on three premises:

1. the actual existence (thubüt) of a contradiction between reason and revelation;

2. limiting the theoretically possible options for dealing with the alleged contradiction to only the four mentioned, namely: (a) accepting both contradictory statements simultaneously; (b) rejecting both simultaneously; (c) prioritizing revelation over reason as a rule; or (d) prioritizing reason over revelation as a rule;

3. the invalidity of the first three alternatives in Premise 2, therefore:

Conclusion: the necessity of the fourth alternative, namely, giving priority as a rule to reason over revelation and reinterpreting revelation accordingly.

Ibn Taymiyya rejects all three of these premises as invalid. His attempt to prove the falsity of Premise 1 is the mission of the entire Dar' ${ }^{\prime}{ }^{\mathbf{c}} \bar{a} r u d$. In the sections where he enumerates the bulk of his arguments against the Universal Law, however, Ibn Taymiyya concentrates on undermining Premise 2, which he does by refusing to concede the four-fold division of the premise-namely, accepting both allegedly contradictory indicants, rejecting both, giving unqualified precedence to the rational proof, or giving unqualified precedence to the scriptural indicant. Instead, he holds, it may be that the rational proof is to be given priority in some instances, while the scriptural indicant is to take precedence in others. How is this so? Ibn Taymiyya explains: If two proofs or indicants contradict each other, regardless of whether they are both scriptural, both rational, or one of them scriptural and the other rational, it must be either that they are both conclusive (qat $t^{t} \bar{\imath}$, that they are both inconclusive (zannil), or that one is conclusive and the other inconclusive. Should it turn out that they are both conclusive ( $\left.q a t^{\dagger} \mathfrak{\imath}\right)$, then it is theoretically impossible that they should contradict regardless of whether they both be rational, both be scriptural, or one rational and the other scriptural. It follows, therefore, that if two conclusive indicants were to be contradictory, or if one of them were to contradict that which is indicated or established by the other, this would entail a violation of the law of non-contradiction, which is impossible. Rather, for any two indicants believed to be conclusive and that are also surmised to contradict one another, it must necessarily be that one of them is not, in fact, conclusive, or that the respective propositions they establish are not, upon closer scrutiny, in actual contradiction.

Now, Ibn Taymiyya argues, should it turn out that one of the indicants is conclusive to the exclusion of the other, then priority must be given to the conclusive indicant by the consensus of all rational individuals ('uqala'), regardless of whether it comes from scripture or reason, since mere supposition cannot override certainty. If both indicants are merely presumptive and inconclusive (zann $\vec{l})$, then one must investigate which of them is more

37 Ibn Taymiyya's development and discussion of the dichotomy "knowledge vs. conjecture" is located primarily in Arguments 1 (Dar', I: 86-87), 2 (I: 87), 4 (I: 134-37), and 5 (I: 137). 
strongly founded and therefore more probative ( $r \bar{a} j i h$ ), then prioritize the stronger one over the weaker one by virtue of its superior probative value-regardless, once again, of its epistemological origin (whether scriptural or rational). ${ }^{38}$ It follows from this, therefore, that the claim that one must give precedence in an absolute manner either to the scriptural or to the rational proof on pain of violating either the law of non-contradiction or the law of the excluded middle is a false claim, for there indeed exists a possibility other than the four mentioned above, namely, that precedence be given to whichever of the two indicants is either conclusive or, barring conclusiveness, more probative than the other, regardless whether scriptural or rational. This last procedure, asserts Ibn Taymiyya, is the correct one. ${ }^{39}$

The only possible objection to this rule, Ibn Taymiyya asserts, would be to maintain that a scriptural indicant can never be conclusive. But this argument, quite apart from the fact that it lacks validity, ${ }^{40}$ is of no use, for in this case, the indicant given priority would still be prioritized on account of its being conclusive, not on account of its being rational nor on account of its "grounding" of revelation, while those who adhere to the Universal Law have made the primary basis on which they give priority to the rational indicant its alleged grounding of revelation, a position that does not stand up to scrutiny. ${ }^{41}$ Any rational person, Ibn Taymiyya explains, would agree that if a conclusive and an inconclusive indicant

38 Dar', I: 78-79.

39 Ibid., I: 87, lines 5-11.

40 Ibn Taymiyya's stance here runs contrary to the principle espoused by al-Rāzì, namely, that it is im-

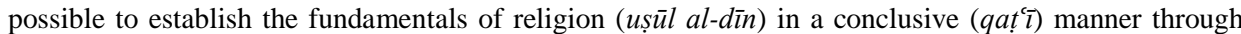
textual evidence, since reasoning (istidla $l$ ) from scripture is dependent upon presumptive (zann $\vec{\imath}$ - - that is, less than fully conclusive (qat $t^{c} \bar{l}$ - - factors. Such "presumptive" factors include, for al-Rāzī: the transmission of the lexicon, syntax, and morphology of the language; verification of the absence of figurative usage (majāz), implicit signification (iḍmār), particularization of a general term (takhșiș), polyvalence (ishtirāk), or transposition of meaning (naql); and, beyond such linguistic and hermeneutic concerns, establishing that there exists no valid rational objection (mu'ārid 'aqlī) to the texts' obvious

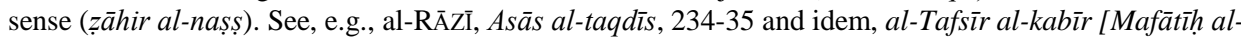
ghayb], 32 vols. ([Cairo]: al-Mațba'a al-Bahiyya al-Mișriyya, 1354-1357/1935-1938), XXIV: 181, discussed at EL-ToBGUi, "The Hermeneutics of Fakhr al-Dīn al-Rāzī," 139-40. Debilitatingly, however, al-Rāzì holds that the knowledge that no rational objection exists is, in fact, impossible to come by, since it is always conceivable that there might exist an intrinsically (" $f$ i nafs al-amr") valid rational objection to what the Qur'ān states which simply has not occurred to the person encountering a given Qur'ānic verse or hadīth report. See, e.g., al-RĀZī, Mațālib, 116-17; Muhașșal, 51; Arba'īn, II: 251-54; and Ma'älim, 25. Ibn Taymiyya states that in a work he wrote entitled Sharh awwal al-Muhașșal, he had responded to al-Rāzī's allegations that arguments deduced from scripture could never be definitive and that he had argued, to the contrary, that such arguments can indeed yield certitude. [This work-cited in, among others, Muhammad b. 'Abd Allāh IBN RuSHAYYIQ, Asmā’ mu'allafāt Ibn Taymiyya, ed. Șalāḥ al-Dīn al-Munajjid (incorrectly ascribed to Ibn Qayyim al-Jawziyya), 2 ed. (Damascus: al-Majma' al'Ilmī al-'Arabī, 1953), 19 and Muhammad b. Ahmad IBN 'ABD AL-HĀDī, al-'Uqūd al-durriyya min manāqib Shaykh al-Islām Aḥmad b. Taymiyya, ed. Ab̄̄ Muș`ab Țal'at b. Fu’ād al-Hulwān̄̄ (Cairo: alFārūq al-Hadītha, 2002), 37-has unfortunately not come down to us. See Dar', I: 22, n. 4.] In the current work - that is, the Dar' ta'ärud-his goal is to refute the notion of the "rational objection" and to nullify the position of those who claim that rational proofs and arguments are to be given unqualified priority over scriptural indicants.

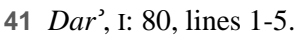

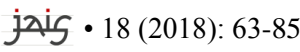


contradict, then the conclusive one must be given preference. It is thus invalid to accord automatic priority to one category of proof over another. Rather, one must investigate any two specific pieces of evidence found to be in contradiction on a particular point and take as preponderant whichever one is definitive $(q a t+i \bar{l})$, or whichever one is more probative ( $r \bar{a} j i h)$ if both are less than fully conclusive, regardless of whether the indicant thus preferred be the scriptural or the rational one. ${ }^{42}$

In conclusion, Ibn Taymiyya seeks to replace the binary "reason vs. revelation" with the alternative binary "knowledge vs. conjecture." He does so by arguing that discrete arguments based on either what is considered reason or what is considered authentic scripture run the entire scale of epistemic warrant from "certain" to "fallacious" and that, therefore, precedence must in every case be given to whatever argument on a given question happens to be more probative, regardless from which of the two sources of knowledge, reason or revelation, we have it. Once Ibn Taymiyya has essentially equated the two sources - reason and revelation-epistemically while simultaneously subjecting each discrete element of both categories to a common test of probity, he completes this second maneuver against the Universal Law by declaring that the issue is not, as everyone seems to have assumed, reason vs. revelation, but rather knowledge vs. conjecture, certainty vs. uncertainty, and more probative vs. less probative indications of truth.

Taken together, Arguments 1 through 5-addressing what it means for reason to "ground" revelation and establishing the crucial binary "knowledge vs. conjecture" as opposed to "reason vs. revelation"-aim to undermine the main premises upon which the Universal Law is built.

\section{Not "reason vs. revelation" but "scripturally validated vs. scripturally non-validated"}

Ibn Taymiyya's insistence that the relevant distinction to be made is between knowledge and conjecture, rather than between reason (as a category) and revelation (as a category), has immediate implications for the epistemological status, as well as the religious-moral evaluation, of various arguments and proofs. In Argument $15,{ }^{43}$ Ibn Taymiyya elaborates a fundamental distinction by means of which he attempts to shift the entire frame of reference in the debate concerning reason and revelation. According to him, the real issue is not a question of "scriptural" vs. "rational" $\left(\operatorname{shar}^{c} \bar{\imath} \neq{ }^{\prime} a q l \vec{l}\right)$ proofs and methods, which is how the debate had almost always been framed by virtually all parties up until his time, but rather a question of "scripturally validated" vs. "scripturally non-validated" ( $\left.\operatorname{shar}^{\top} \bar{l} \neq \operatorname{bid}^{\varsigma} \bar{\imath}\right)$ proofs and methods. Scripturally validated $\left(\operatorname{shar}^{c} \vec{\imath}\right)$ proofs, in turn, comprise both revealed $\left(\operatorname{sam}^{c} \vec{\imath}\right)$ and rational ('aqlī) indicants. The $\operatorname{shar}^{c} \bar{l}-b_{i d}{ }^{c} \bar{l}$ binary is based, for Ibn Taymiyya, on the fact that an indicant's being classed as "scriptural" or "rational" is not in and of itself a property that entails praise or blame, validity or invalidity. Rather, this merely reveals the way in

42 Ibid., I: 136, line 5 - 137, line 8 .

43 See ibid., I: 198-200 for Argument 15 and the full presentation of Ibn Taymiyya's novel binary "shar ${ }^{\imath}$

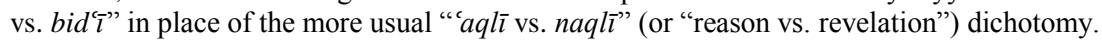


which the thing in question has come to be known-either by way of reason or by way of revelation-even though, when revelation is the source, reason must also be used in conjunction with it. ${ }^{44}$

The binary that results from this reclassification of indicants and proofs is no less than fundamental to Ibn Taymiyya's thought and methodology. The counterpart of a scriptural ( $\left.\operatorname{shar}^{c} \bar{\imath}\right)$ indicant, he tells us, is not a rational one, but rather an innovated (bid $\left.{ }^{c} \mathfrak{l}\right)$ one, one that lacks scriptural validation, for it is "innovation" (bid'a), and not "reason," that stands opposite to "scripture" (shir'a). ${ }^{45}$ Being "scripturally validated" (shar $\left.{ }^{c} \vec{l}\right)$ is a positive attribute of an indicant or proof, whereas being "innovated" (bid" $\mathfrak{l}$ ) - not in the sense of merely being new, but of lacking scriptural validation - is a negative qualification, for whatever stands opposed to true revelation $\left(\operatorname{sharl}^{-} a\right)$ is of necessity invalid and false. Now, a scripturally validated $\left(\operatorname{shar}^{i} \bar{l}\right)$ indicant may consist of either a revealed text or a conclusion reached through reason, for a proof's being "scripturally validated" can mean one of two things, either (1) that revelation has positively affirmed and explicitly indicated it (kawn al-shar' athbatahu wa-dalla 'alayhi), or (2) that revelation has permitted it and declared it valid and licit (kawn al-shar cabāhahu wa-adhina fihi), that is, either by way of affirmation or of approbation. ${ }^{46}$

Now, if one uses "scriptural" ( $\operatorname{shar}^{c} \bar{l}$ ) according to the first meaning-i.e., that which scripture has positively affirmed and indicated - then it is possible that the indicant or proof in question also be knowable through the use of reason, with the role of scripture here being to point it out (dalla 'alayhi) and call attention to it (nabbaha 'alayhi). In this case, the indicant is classified as a "scripturally validated rational indicant" (sharc-'aqlī). Ibn Taymiyya cites as examples of scripturally validated rational indicants things such as the various parables (amthāl) mentioned in the Qur'ān and other arguments for the oneness of God and the authenticity of the Prophet, the affirmation of God's attributes, and similar matters. All these, affirms Ibn Taymiyya, are proofs whose truth is known by reasonconsisting as they do of rational demonstrations and syllogisms (barāhīn wa-maqāyis 'aqliyya) - yet they are also classified as scripturally validated, in the sense meant here, by virtue of being mentioned in and explicitly affirmed by the Qur'ān. If, on the other hand, a given scripturally validated indicant is known exclusively through the texts of revelation, then it is classified as a "scripturally validated revealed indicant" ( $\left.\operatorname{shar}^{(} \bar{l}-\operatorname{sam}^{c} \hat{\imath}\right)$. In summary, then, valid scriptural indicants are categorized as either "scriptural-rational" $\left(\operatorname{shar}^{c} \bar{l}-{ }^{\prime} a q l \bar{l}\right)$ or "scriptural-revealed" $\left(\operatorname{shar}^{c} \bar{l}-\operatorname{sam}^{c} \hat{l}\right)$, that is, scripturally validated rational indicants or scripturally validated revealed indicants.

Many kalām theologians, Ibn Taymiyya insists, have made the error of presuming that the category of scriptural indicants consists exclusively of this second type of indicant $\left(\operatorname{shar}^{\mathrm{c}} \bar{l}-\operatorname{sam}^{\mathrm{c}} \hat{\mathrm{l}}\right)$ - namely, that which can only be known through the texts of revelation - and that revelation is only capable of functioning as an indicant (dalīl) of something in this

44 In order, Ibn Taymiyya seems to imply, to determine that something is actually a part of authentic revelation and, having done so, properly to understand the import thereof. In other words, reason is employed in the determination of both the authenticity and reliability (thubüt) of the revealed texts and the meaning (daläla) thereof, as we have discussed in the preceding section.

45 “idh al-bid'a tuqābilu 'l-shir'a.” Ibid., I: 198, line 6.

46 See ibid., I: 198, lines 3-9.

jais • 18 (2018): 63-85 
manner, that is, purely by informing us of matters of which we could otherwise have no knowledge. For this reason, they separate the "fundamentals of faith" ( ușūl al-dīn) into two categories, rational and scriptural, and define the rational strictly as that which is not, and cannot be, known by means of revelation (and, conversely, define the scriptural strictly as that which is not, and cannot be, known by means of reason). Yet they are erroneous in doing so, Ibn Taymiyya insists, for the Qur'ān also employs, indicates, and draws attention to rational indicants. Indeed, some of what is classified as "rational indicants" comprises that which can be inferred by reason on the basis of empirical evidence, ${ }^{47}$ and the Qur'ān itself indicates this in verses such as: "We shall show them Our signs in the horizons and in themselves until it becomes clear to them that it is the Truth. Is it not sufficient that thy Lord is witness to all things?"48 The purpose of a verse such as this one, we understand, is to advance a rational argument for the existence of God based on the existence and nature of the empirical world around us.

If, however, one uses the term "scriptural" or "scripturally validated" ( $\left.\operatorname{shar}^{\mathrm{c}} \bar{\imath}\right)$ according to the second meaning mentioned above-i.e., that which scripture has permitted and deemed licit (though has not itself positively affirmed or established) - then this category, according to Ibn Taymiyya, comprises several subcategories, namely: that which has reached us of the authenticated prophetic Sunna; that to which the Qur'ann has drawn attention and indicated in terms of rational proofs and arguments; and, finally, that which can be inferred on the basis of our empirical observation of existent things ( $m \bar{a}$ dallat 'alayhi wa-shahidat bihi al-mawjūdāt), elevating hereby empirical observation to the category of $\operatorname{shar}^{c} \bar{l}$, or scripturally validated, evidence as well. ${ }^{49}$

By way of summary, an indicant that is scripturally validated (dalīl shar ${ }^{c} \vec{l}$ ) may not be contradicted by or subordinated to one that is not scripturally validated ( ghayr shar $^{c} \bar{l}$ ). As for indicants that are either rational ( $\left.{ }^{c} a q l \vec{\imath}\right)$ or have the nature of a transmitted report ( $\left.\operatorname{sam}^{c} \hat{\imath}\right)$ but that are not scripturally validated $\left(\operatorname{shar}^{c} \bar{\imath}\right),{ }^{50}$ such indicants may sometimes outweigh countervailing evidence and sometimes themselves be outweighed, sometimes valid and sometimes invalid. ${ }^{51}$ As for the statements of authentic revelation, both declarative and imperative, these may not be overridden or contradicted ( $y u^{c} \bar{a} r a d$ ) by anything. Unfortunately, however, there are those who include in the category of "scriptural proofs and indicants" (adilla shar iyya) that which does not belong to it (i.e., specious and invalid rational arguments), as there are those who exclude from it that which is, in fact, a proper subcategory of it - such as, we may assume, scripturally validated rational ( $\left.\operatorname{shar}^{c} \bar{l}-{ }^{c} a q l \bar{l}\right)$ arguments, an important category of $\operatorname{shar}^{\complement} \bar{\imath}$ indicants which Ibn Taymiyya blames the kalām

47 “wa-in kāna min al-adilla al-‘aqliyya mā yu'lamu bi’l-'iyān wa-lawāzimihi.” Ibid., I: 199, lines 9-10.

48 Q. Fușșilat 41:53. See Dar’, I: 198, line 9-199, line 12.

49 See ibid., I: 199, lines 13-14.

50 Such as, for example, a historical or other sort of "report" or piece of information that is neither affirmed, nor denied, nor addressed by revelation in any way.

51 As in the case of rational arguments containing false premises or built on invalid inferences, or hadith texts transmitted as putative revelation but found, upon investigation and criticism, to be inauthentic. 
theologians for having made the fundamental error of excluding from the category of scriptural proofs. ${ }^{52}$

In conclusion, then, Ibn Taymiyya completes his bid to redefine the terms of the debate on reason and revelation through proposing now a third conceptual shift: namely, that proofs are not diametrically opposed in terms of being "scriptural" ( $\left.\operatorname{shar}^{\mathrm{\imath}} \overrightarrow{\mathrm{l}}\right)$ versus "rational" ( $\left.{ }^{\prime} a q l \vec{\imath}\right)$, but rather in terms of being "scripturally legitimated" ( $\left.\operatorname{shar}^{(} \bar{\imath}\right)$ versus "scripturally non-legitimated" (bid $\left.{ }^{c} \bar{l}\right)$. The category of scripturally legitimated ( $\left.\operatorname{shar}^{\mathrm{c}} \bar{l}\right)$ proofs, he argues, comprises both the authentic texts of revelation properly comprehended and valid rational arguments built on sound premises. Ibn Taymiyya thus attempts to divide what passes for "reason" against itself into two categories — valid/true and invalid/false - and to absorb the first part, i.e., that which is valid, ${ }^{53}$ into the larger umbrella category of scripturally legitimated $\left(\operatorname{shar}^{c} \hat{\imath}\right)$ proofs. Through his rigorous insistence on the epistemic quality of a proof to the exclusion of all other considerations - including whether the proof originates in revelation or in reason-Ibn Taymiyya attempts to circumvent the rigid categories of "reason" taken as all of a piece and "revelation" taken as all of a piece, subjecting instead each discrete element of both categories to a common test of epistemic warrant, then asserting that revelation approves and legitimates everything that is true and certain and abjures everything that is false and unfounded-regardless whether it originates in reason or what is claimed to be divine revelation.

\section{Concluding summary}

To summarize, Ibn Taymiyya, as we have seen in Sections V through VII above, makes three fundamental moves in his attempt to refute the Universal Law. He first implodes the fixed categories of "revelation" and "reason" by lining up all the discrete elements of both on a par. He then insists that each discrete element, whether from reason or from revelation, be individually investigated for its probative value, thus replacing the binary "reason vs. revelation" ('aql-naql) with the binary "knowledge vs. conjecture" ('ilm-zann) or "more certain vs. less certain" (räjihh-marjūhn) indicants of truth. Finally, he subsumes valid rational argumentation based on sound premises under the larger category of "scripturally validated" $\left(\operatorname{shar}^{c} \vec{l}\right)$ proofs, making of them a new category he terms "scriptural-rational" ( $\left.\operatorname{shar}^{c} \bar{l}-{ }^{\prime} a q l \bar{l}\right)$, the counterpart of the "scriptural-revealed" ( $\left.\operatorname{sar}^{c} \bar{l}-\operatorname{sam}^{c} \hat{l}\right)$. By these three maneuvers, Ibn Taymiyya seeks to tear down the canvas altogether, so to speak, and to redraw from scratch the very terms of the debate surrounding reason and revelation in medieval Islam. He attempts this tour de force by first poking holes in all the major assumptions upon which the Universal Law is based, and then redefining the categories themselves in terms of which the whole question of "reason and revelation" had been conceived and debated up to his time.

52 See ibid., I: 200 , line $8 \mathrm{ff}$.

53 What exactly constitutes valid and invalid reasoning and rational proofs for Ibn Taymiyya deserves a separate study and cannot be taken up in detail here.

jais • 18 (2018): 63-85 


\section{Bibliography}

Abrahamov, Binyamin. 1992. "Ibn Taymiyya on the Agreement of Reason with Tradition." Muslim World, 82.3: 256-73.

— . 1995. "The 'Bi-lā Kayfa' Doctrine and Its Foundations in Islamic Theology.” Arabica, 42.3: 365-79.

ADAmSOn, Peter (ed.). 2011. In the Age of Averroes: Arabic Philosophy in the Sixth/Twelfth Century. London: The Warburg Institute, School of Advanced Study, University of London.

ADEM, Rodrigo. 2015. “The Intellectual Genealogy of Ibn Taymīya.” Ph.D. dissertation, University of Chicago.

Ansum, Ovamir. 2012. Politics, Law, and Community in Islamic Thought: The Taymiyyan Moment. New York: Cambridge University Press.

ARNALDEZ, Roger. 1960. "L'œuvre de Fakhr al-Dīn al-Rāzī : commentateur du Coran et philosophe." Cahiers de civilisation médiévale, $X^{e}-X I I^{e}$ siècles, 3: 307-23.

al-BAGHDĀDĪ, 'Abd al-Qāhir. Kitāb Ușūl al-dīn. Istanbul: Maṭba at al-Dawla, 1346/1928.

al-BĀQILlĀNī̄, Abū Bakr Muhammad b. al-Ṭayyib. Kitāb al-Tamhīd. Edited by Richard Joseph McCarthy. Beirut: al-Maktaba al-Sharqiyya, 1957.

EL-ToBgui, Carl Sharif. 2008. "The Hermeneutics of Fakhr al-Dīn al-Rāzī.” In MoHAMmEd \& RiPPIN (eds.) 2008: 125-58.

al-GHAZĀLī, Abū Ḥāmid. al-Iqtiṣād fì 'l-i tiqqād. Edited by 'Abd Allāh Muḥammad al-Khalīlī. Beirut: Dār al-Kutub al-'Ilmiyya, 1424/2004.

—. Fayșal al-tafriqa bayna 'l-Islām wa'l-zandaqa. Edited by Maḥmūd Bījū. Istanbul[?]: Dār alBayrūtī, 1413/1993.

—. Qānūn al-ta’wīl. Edited by Mạ̣mūd Bījū. [n.p.], 1413/1992.

GOLDZIHER, Ignaz. 1912. “Aus der Theologie des Fachr al-dīn al-Rāzī.” Der Islam, 3: 213-47.

GRIFFEL, Frank. 2009. Al-Ghazālī’s Philosophical Theology. Oxford: Oxford University Press.

—. 2011. "Between al-Ghazālī and Abū 1-Barakāt al-Baghdādī: The Dialectical Turn in the Philosophy of Iraq and Iran During the Sixth/Twelfth Century." In ADAMSON (ed.) 2011: 45-75.

—. 2015. "Al-Ghazālī at His Most Rationalist: The Universal Rule for Allegorically Interpreting Revelation (al-Qānūn al-Kullī fì t-Ta’wīl).” In TAMER (ed.) 2015: 89-120.

- . 2018. "Ibn Taymiyya and His Ash'arite Opponents on Reason and Revelation: Similarities, Differences, and a Vicious Circle." The Muslim World, 108: 11-39.

ḤĀJJī KhalīFA, (Mușțafà b. 'Abd Allāh). Kashf al-z̦unūn 'an asāmī al-kutub wa'l-funūn. Edited by Muḥammad Sharaf al-Dīn Yāltaqāyā and Rif'at Bīlgeh al-Kilīsī. 2 vols. Beirut: Dār Iḥyā' alTurāth al-'Arabī, [1360]/1941.

HAllaQ, Wael B. 1993. Ibn Taymiyya against the Greek Logicians. Oxford: Oxford University Press.

HEER, Nicholas. 1993. "The Priority of Reason in the Interpretation of Scripture: Ibn Taymīyah and the Mutakallimūn." In MIR (\& Fossum) (ed.) 1993: 181-95.

— . 1998. “Al-Ghazali: The Canons of Ta’wil.” In RENARD (ed.) 1998: 48-54.

IBN 'ABD AL-HĀDī, Muhammad b. Ahmad. al-'Uqūd al-durriyya min manāqib Shaykh al-Islām Ahmad b. Taymiyya. Edited by Ab̄̄ Muș ab Țal'at b. Fu’ād al-Ḥulwān̄i. Cairo: al-Fārūq alHadītha, 2002.

IBN AL-'ARABī, al-Qāộ̄ Abū Bakr. al-'Awāṣsim min al-qawāṣsim. Edited by 'Ammār Ṭālibī. Cairo: Maktabat Dār al-Turāth, 1394/1974. 


\section{Carl Sharif El-Tobgui}

- Qānūn al-ta’wīl. Edited by Muhammad al-Sulaymān̄̄. Jeddah: Dār al-Qibla li’l-Thaqāfa alIslāmiyya, 1406/1986.

IBN RushayYiQ, Muḥammad b. 'Abd Allāh. Asmā' mu'allafāt Ibn Taymiyya. Edited by Șalāḥ al-Dīn al-Munajjid (incorrectly ascribed to Ibn Qayyim al-Jawziyya). 2 ed. Damascus: al-Majma ${ }^{`}$ al-'Ilmī al-'Arabī, 1953.

Page |84 IBn TAYmiYya, Taqī al-Dīn Ahmad. Dar' ta'āruḍ al-'aql wa'l-naql, aw Muwāfaqat șaḥ̄h al-manqūl li-șarịh al-ma'qūl. Edited by Muhammad Rashād Sālim. 11 vols. Riyadh: Dār al-Kunūz alAdabiyya, 1399/1979.

- Kitāb al-Radd 'alà 'l-mantiqiyyīn, al-musammà aydan Nașịhat ahl al-īmān fì 'l-radd 'alà mantiq al-Yūnān. Edited by 'Abd al-Ṣamad Sharaf al-Dīn al-Kutubī. Beirut: Mu'assasat al-Rayyān, $1426 / 2005$.

JACKSON, Sherman A. 2002. On the Boundaries of Theological Tolerance in Islam: Abü Hāmid alGhazālì's Fayșal al-Tafriqa. Oxford: Oxford University Press.

JAFFER, Tariq. 2015. Rāzī: Master of Qur'ānic Interpretation and Theological Reasoning. New York: Oxford University Press.

al-JUWAYNī, Imām al-Haramayn 'Abd al-Malik b. 'Abd Allāh. Kitāb al-Irshād ilà qawātị' al-adilla fì ușūl al-i'tiqād. Edited by Muhammad Yūsuf Mūsà and 'Alī 'Abd al-Mun'im 'Abd al-Ḥamīd. Cairo: Maktabat al-Khānjīi, 1369/1950.

al-KhūNAJī, Afụal al-Dīn. Kashf al-asrār 'an ghawāmị̆ al-afkār. Edited by Khaled El-Rouayheb. Tehran: Iranian Institute of Philosophy; Berlin: Institute of Islamic Studies, Free University of Berlin, 2010.

Мiснот, J. Yahya. 2001. "Vanités intellectuelles... L'impasse des rationalismes selon le Rejet de la contradiction d'Ibn Taymiyyah." Oriente Moderno, 19, no. 80: 597-617.

MiR, Mustansir (ed., in collab. with J. E. Fossum). 1993. Literary Heritage of Classical Islam: Arabic and Islamic Studies in Honor of James A. Bellamy. Princeton: Darwin Press.

Mohammed, Khaleel, and Andrew RipPIN (eds.). 2008. Coming to Terms with the Qur'ān: A volume in honor of Professor Issa Boullata, McGill University. North Haledon, New Jersey: Islamic Publications International.

ÖZERVARLI, M. Sait. 2010. "The Qur’ānic Rational Theology of Ibn Taymiyya and his Criticism of the Mutakallimūn." In RAPOPORT \& AHMED (eds.) 2010: 78-100.

RAHMAN, Fazlur. 2008. Prophecy in Islam: Philosophy and Orthodoxy. New York: Routledge.

RAPOPORT, Yossef, and Shahab AhMED (eds.). 2010. Ibn Taymiyya and His Times. Oxford: Oxford University Press.

al-RĀZī, Fakhr al-Dīn Muhammad b. 'Umar. al-Arba'īn fì uṣūl al-dīn. Edited by Aḥmad Hijāzī alSaqqā. 2 vols. Cairo: Maktabat al-Kulliyyāt al-Azhariyya, 1406/1986.

— . al-Masā̉il al-khamsūn fì uṣūl al-dīn. Edited by Aḥmad Ḥijāzī al-Saqqā. Beirut: Dār al-J̄̄il; Cairo: al-Maktab al-Thaqāfî, 1410/1990.

— al-Matālib al-'âliya min al-'ilm al-ilāhī. Edited by Aḥmad Ḥijāzī al-Saqqā. 9 vols. Beirut: Dār alKitāb al-'Arabī, 1407/1987.

— al-Tafsīr al-kabìr [Mafātīh al-ghayb]. 32 vols. [Cairo]: al-Mațbáa al-Bahiyya al-Mișriyya, 13541357/1935-1938.

—. Asās al-taqdīs. Edited by Ahmad Hijāzī al-Saqqā. Cairo: Maktabat al-Kulliyyāt al-Azhariyya, 1406/1986.

—. Ma'ālim uṣūl al-dīn. Edited by Țāhā `Abd al-Ra’ūf Sa`d. Beirut: Dār al-Kitāb al-'Arabī, 1404.

زحن 18 (2018) : 65 
Ibn Taymiyya on the Incoherence of the Theologians' Universal Law

—. Mafātīh al-ghayb (al-Tafsīr al-kabìr). 32 vols. Beirut: Dār al-Fikr, 1401/1981.

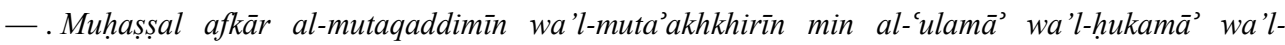
mutakallimīn. Edited by Țāhā 'Abd al-Ra'ūf Sa'd. Cairo: Maktabat al-Kulliyyāt al-Azhariyya, 1978[?].

—. Nihāyat al-'uqūl fì dirāyat al-uṣūl. Edited by Sa'̄id 'Abd al-Lațīf Fūda. 4 vols. Beirut: Dār alDhakhā'ir, 1436/2015.

RENARD, John (ed.). 1998. Windows on the House of Islam: Muslim Sources on Spirituality and the Religious Life. Berkeley: University of California Press.

al-Shahrastānī, Muhammad b. 'Abd al-Karīm. Kitāb Nihāyat al-iqdām fì 'ilm al-kalām. Edited by Alfred Guillaume. Cairo: Maktabat al-Thaqāfa al-Dīniyya, 1430/2009.

al-SuYŪṬī, Jalāl al-Dīn. "Jahd al-qarīha fì tajrīd al-Nașịha." In Șawn al-manțiq wa'l-kalām 'an fann al-manțiq wa'l-kalām, wa-yalīhi mukhtașar al-Suyūț̄i [Jahd al-qarīha] li-kitāb Nașīhat ahl alìmān fì 'l-radd 'alà manțiq al-Yūnān li-Taqì al-Dìn b. Taymiyya. Edited by 'Alī Sāmī al-Nashshār, 201-343. Cairo: Maktabat al-Khānjīi, [1947?].

TAMER, Georges (ed.). 2015. Islam and Rationality: The Impact of al-Ghazālī. Papers Collected on His $900^{\text {th }}$ Anniversary. Volume 1. Leiden: Brill.

VAN Ess, Josef. 1966. Die Erkenntnislehre des 'Adudaddīn al-İcī: Übersetzung und Kommentar des ersten Buches seiner Mawāqif. Wiesbaden: Franz Steiner Verlag.

ZougGAR, Nadjet. 2010. "Interprétation autorisée et interprétation proscrite selon le Livre du rejet de la contradiction entre raison et révélation de Taqī l-Dīn Ahmad b. Taymiyya." Annales Islamologiques, 44: 195-206.

—. 2014. "Aspects de l'argumentation élaborée par Taqī 1-Dīn Ahmad b. Taymiyya (m. 728/1328) dans son livre du Rejet de la contradiction entre raison et Écriture (Dar' ta'ārud al-'aql wa-lnaql)." Arabica, 61.1-2: 1-17.

(C) Carl Sharif El-Tobgui, Brandeis University, Waltham, MA

$\checkmark$ eltobgui@brandeis.edu 